
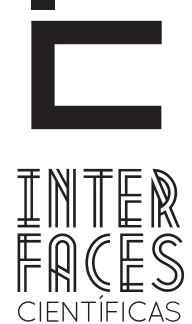

DIREITO

ISSN IMPRESSO 2316-3321

E - ISSN 2316-381X

DOI - 10.17564/2316-381X.2017v6n1p53-74

\title{
A MITIGACG̃̃O DOS RISCOS DO COMÉRCIO DE CRIANÇAS PELA ADOÇÃO INTUITO PERSONAE
}

\author{
THE MITIGATION OF THE RISKS OF CHILD TRADE TO INTUITO PERSONAE ADOPTION
}

LA MITIGACIÓN DE LOS RIESGOS DEL COMERCIO DE NIÑOS POR LA ADOPCIÓN INTUITU PERSONAE

Fernanda Trentin ${ }^{1}$

\section{RESUMO}

0 artigo buscou encontrar eventuais riscos advindos do deferimento da adoção intuito personae em relação ao comércio de crianças, considerando que tal modalidade de adoção ocorre quando a genitora indica a pessoa para quem deseja adotar seu filho. Nesse sentido, buscou-se verificar se a adoção consentida ou intuitu personae pode influenciar ou facilitar o comércio de crianças e adolescentes. Vale dizer que tal espécie não é admitida na legislação pátria, o que pode justificar o tema do presente artigo. Buscou-se estudar os aspectos gerais relacionados à adoção no ordenamento jurídico brasileiro, como a evolução histórica, conceitos, requisitos e efeitos da adoção, dentre outros. Utilizando-se de entendimentos doutrinários e jurisprudenciais, foram analisados eventuais riscos e benefícios trazidos pela adoção consentida ou intuitu personae, concluindo-se que os benefícios à criança são maiores que eventuais riscos advindos deste tipo de adoção.

\section{PALAVRAS-CHAVE}

Comércio. Adoção. Criança. 


\section{ABSTRACT}

The article sought to find possible risks arising from the deferment of the intuitu personae adoption in relation to the trade of children, considering that this type of adoption occurs when the mother indicates the person to whom she wishes to adopt her child. In this sense, we tried to verify if the adopted consent or intuitu personae can influence or facilitate the commerce of children and adolescents. It is worth mentioning that such a species is not allowed in the national legislation, which may justify the theme of this article. It was sought to study the general aspects related to adoption in the Brazilian legal system, such as historical evolu- tion, concepts, requirements and effects of adoption, among others. By using doctrinal and jurisprudential understandings, we analyzed possible risks and benefits brought by consent or intuitu personae, concluding that the benefits to the child are greater than eventual risks arising from this type of adoption.

\section{KEYWORDS}

Trade. Adoption. Child.

\section{RESUMEN}

El artículo buscó encontrar eventuales riesgos provenientes de la aceptación de la adopción intuitu personae en relación al comercio de niños, considerando que tal modalidad de adopción ocurre cuando la genitora indica a la persona que desea adoptar a su hijo. En ese sentido, se buscó verificar si la adopción consentida o intuitu personae puede influenciar o facilitar el comercio de niños y adolescentes. Es decir, que tal especie no es admitida en la legislación patria, lo que puede justificar el tema del presente artículo. Se buscó estudiar los aspectos generales relacionados a la adopción en el ordenamiento jurídico brasileño, como la evolución histórica, conceptos, requisitos y efectos de la adopción, entre otros. En el caso de que se trate de entendimientos doctrinarios y jurisprudenciales, se analizaron eventuales riesgos y beneficios traídos por la adopción consentida o intuitu personae, concluyendo que los beneficios al niño son mayores que eventuales riesgos derivados de este tipo de adopción.

\section{PALABRAS CLAVE}

Comercio. Adopción. Niños. 


\section{INTRODUÇ̄̃̃O}

A adoção é uma modalidade de colocação em família substituta, efetivada mediante processo judicial, que por sua vez segue rigorosamente a lei vigente. No entanto, a prática leva ao estudo de modalidades de adoção não previstas na lei ou até mesmo proibidas.

0 tema principal do presente artigo é justamente a adoção consentida, também denominada adoção intuitu personae, modalidade que não possui previsão legal no ordenamento jurídico brasileiro, porém existem decisões que optaram pelo seu deferimento. Busca-se observar, nessa linha de raciocínio, se este tipo de adoção poderia facilitar o comércio de crianças e adolescentes, considerando que não passaria pelos requisitos legais.

\section{ADOÇÃO NO ORDENAMENTO JURÍDICO BRASILEIRO E A ADOÇ̃̃O INTUITO PERSONAE}

A adoção é a principal modalidade de inserção em família substituta, concedendo aos envolvidos o vínculo afetivo, psicológico e espiritual do núcleo familiar. A criança passa a saber como é ter pais e os pais passam a sentir a emoção de como é ter um filho, exercendo assim, efetivamente, a paternidade independentemente de existir entre eles alguma relação de parentesco ou afinidade. (ROLF, p. 462).

De todas as modalidades de família substituta a adoção é considerada a mais abrangente, pois insere o adotando ao núcleo familiar, fazendo com que ele se torne um novo membro da família, mesmo que entre eles inexista biologicamente essa ligação. Então, verifica-se que a lei prevê que o adotando passa a ser filho, não podendo sofrer nenhuma discriminação em relação aos filhos biológicos, conforme previsto no art. 227, $\S 6^{\circ}$, CF que nos contempla com o seguinte: "Os filhos, havidos ou não da relação do casamento, ou por adoção, terão os mesmo direitos e qualifica- ções, proibidas quaisquer designações discriminatórias relativas à filiação".

Diversas são as modalidades de adoção permitidas no Brasil. A adoção consentida, não entanto, não possui previsão legal, porém existem decisões que optaram pelo seu deferimento.

Conforme o informativo 385 do Superior Tribunal de Justiça (STJ), o entendimento que prevalece é pela procedência da adoção intuitu personae, desde que exista vínculo de afeto entre o adotante e o adotando. Hoje, a adoção intuitu personae encontra-se em projeto de lei, nessa situação as pessoas ficam com medo de buscar o ordenamento jurídico para regularizar a adoção que já ocorreu, o que acaba fazendo com que as pessoas optem pela adoção 'a brasileira' sendo esta considerada ilegal. Neste sentido Maciel (2007, p. 223):

\begin{abstract}
É importante a aceitação da adoção intuitu personae, pois sua negação fará com que as pessoas tenham medo de comparecer às Varas da Infância para regularizar sua situação com a criança, o que acarretará duas coisas: que permaneçam com a criança de modo totalmente irregular ou que realizem a adoção "à brasileira”.
\end{abstract}

Fundamento no informativo se manifesta Maciel (2007, p. 221): “[...] sendo demonstrada a existência de vínculos afetivos entre a criança e os adotantes, conforme regra constante no art. $28, \S 2^{\circ}$, do Estatuto da Criança e do Adolescente (ECA), estes deverão prevalecer, tendo em vista o melhor interesse da criança."

Para verificar a existência do vínculo afetivo são utilizados alguns parâmetros quanto à idade do bebê ou criança a ser adotada, ou seja, para bebês de até seis meses de idade entende-se que eles ainda não criaram vínculos afetivos com a família que estavam convivendo, fazendo com que a criança seja entregue para a próxima família da lista dos cadastrados. Em se tratando das demais crianças há entendimento que estas devem passar por avaliação interprofissional e que ao final seja emitido um laudo, constatando se há a existência ou não de vínculo afetivo. Não se pode 
afirmar que este método utilizado é correto, tendo em vista que as crianças desde muito pequenas já reconhecem as pessoas que convivem com elas. (MACIEL, 2007).

A adoção consentida ou intuitu personae é aquela em que os pais biológicos escolhem a pessoa para quem desejam adotar seu filho sem que o Poder Judiciário intervenha nessa escolha, neste sentido Madaleno (2009, p. 477): “Adoção intuitu personae é aquela em que os pais dão consentimento para a adoção em relação a determinada pessoa, identificada como pessoa certa ou para um casal específico, estando presentes os demais pressupostos para a adoção". Maciel (2007, p. 220) complementa: "Nesta modalidade de adoção há a intervenção dos pais biológicos na escoIha da família substituta, ocorrendo esta escolha em momento anterior à chegada do pedido de adoção ao conhecimento do Poder Judiciário".

A escolha e entrega da criança ocorre sem nenhuma intervenção das pessoas que compõe o sistema da justiça da infância e juventude. O contato entre os pais biológicos e os que irão adotar, ocorre, via de regra, durante a gestação, abrangendo todo o período e os pretendentes à adoção prestam auxílios à gestante. Ocorrendo o nascimento do bebê este é entregue a família substituta (MACIEL, 2007). Muitas vezes a entrega da criança se dá pela falta de recursos dos pais biológicos para criá-las, então, conforme Maciel, esta atitude merece compreensão, tendo em vista que os pais, agindo dessa forma, estão pensando no melhor para seus filhos.

Diante da entrega da criança é que surgem diversos problemas, envolvendo esta modalidade de adoção (problemas estes que serão analisados adiante), tendo em vista que não observa os requisitos previstos em lei para sua efetivação.

Em relação ao deferimento ou não da adoção consentida o juiz deverá decidir de acordo com as circunstâncias, ou seja, se entender que a criança deve permanecer com os pretendentes que estão em sua posse, deverá somente regularizar a adoção. Caso opte pelo indeferimento deverá dar destino que entender conveniente para a criança. Todo esse procedimento deverá ocorrer na maior brevidade possível para evitar maiores sofrimentos (MACIEL, 2007).

Em decisão do ano de 2010, observou-se:

CIVIL E PROCESSO CIVIL. DIREITO DA CRIANÇA E DO ADOLESCENTE. APELAÇÃO CÍVEL. AÇÃO DE ADOÇÃO. CASAL FORA DO CADASTRO NACIONAL DE ADOÇÃO, INSTITUÍDO PELA LEI 12.010/09. ADOÇÃO INTUITU PERSONAE (CONSENTIDA). ADMISSIBILIDADE. REGRA GERAL QUE DEVE SER FLEXIBILIZADA, DE ACORDO COM AS PECULIARIDADES DO CASO CONCRETO. PREVALÊNCIA DOS INTERESSES DA CRIANÇA, SOB A GUARDA DOS ADOTANTES DESDE O NASCIMENTO, HÁ APROXIMADAMENTE 1 (UM) ANO. VÍNCULO DE AFETIVIDADE CONSTITUÍDO ENTRE OS PRETENDENTES À ADOÇÃO E O MENOR. PEDIDO JURIDICAMENTE POSSÍVEL, CONFORME JURISPRUDÊNCIA PACÍFICA DO STJ E TRIBUNAIS ESTADUAIS PÁTRIOS, INCLUSIVE DESTA CORTE. APLICABILIDADE DO DISPOSTO NOS ARTIGOS 227 DA CF/88 E 43 DO ECA. SENTENÇA ANULADA. RECURSO CONHECIDO E PROVIDO. ECA - APELAÇÃO CÍVEL - PEDIDO DE ADOÇÃO - EXTINÇÃO DO PROCESSO SEM RESOLUÇÃO DO MÉRITO, ANTE A AUSÊNCIA DE INSCRIÇÃO DOS ADOTANTES NO CADASTRO NACIONAL DE ADOÇÃO - APLICAÇÃO DO PRINCÍPIO DO MELHOR INTERESSE DA MENOR - LAÇOS FAMILIARES ESTABELECIDOS COM OS PRETENSOS ADOTANTES GUARDA EXERCIDA PELO CASAL APELANTE DESDE $O$ NASCIMENTO DA CRIANÇA, COM A CONCORDÂNCIA DA MÃE BIOLÓGICA - FLEXIBILIZAÇÃO DAS NORMAS LEGAIS - MANUTENÇÃO DA CRIANÇA ONDE JÁ SE ENCONTRA, ATÉ QUE SE DECIDA A RESPEITO DA ADOÇÃO - PRECEDENTES - RECURSO CONHECIDO E PROVIDO.12.010227CF/8843ECAECAI - A observância do cadastro de adotantes, vale dizer, a preferência das pessoas cronologicamente cadastradas para adotar determinada criança não é absoluta. Excepciona-se tal regramento, em observância ao princípio do melhor interesse do menor, basilar e norteador de todo o sistema protecionista do menor, na hipótese de existir vínculo afetivo entre a criança e o pretendente à adoção, ainda que este não se encontre sequer cadastrado no referido registro; (STJ; REsp 1172067/MG; Rel. Min. Massami Uyeda; DJ: 18/03/2010). (TJ/RN, AC. 2010. 004375-7, 2a Câmara Cível, Rel. Juíza Convocada Francimar Dias, julgado em 31.08.2010). (43812 RN 2010.004381-2, Relator: Des. Cláudio Santos, Data de Julgamento: 16/11/2010, $2^{\mathrm{a}}$ Câmara Cível).

A decisão citada acima entende que a regra de observância ao cadastro de adotantes não é absoluta, tendo em vista que o que realmente deve prevalecer é o melhor interesse do menor. Neste caso fundamen- 
tou a decisão no artigo 227 da Constituição Federal, artigo este citado anteriormente. Ainda, entende que a decisão relacionada à adoção consentida deve ser flexibilizada, analisando as peculiaridades de cada caso concreto.

Conforme o informativo 385 do STJ, o entendimento que prevalece é pela procedência da adoção intuitu personae, desde que exista vínculo de afeto entre o adotante e o adotando. Hoje, a possibilidade da adoção intuitu personae encontra-se em projeto de lei. Nessa situação, as pessoas ficam com medo de buscar o ordenamento jurídico para regularizar a adoção que já ocorreu, o que acaba fazendo com que optem pela adoção ‘à brasileira' sendo esta considerada ilegal. Neste sentido Maciel (2007, p. 223):

É importante a aceitação da adoção intuitu personae, pois sua negação fará com que as pessoas tenham medo de comparecer às Varas da Infância para regularizar sua situação com a criança, o que acarretará duas coisas: que permaneçam com a criança de modo totalmente irregular ou que realizem a adoção “à brasileira”.

Maciel (2007, p. 221), no mesmo fundamento do informativo se manifesta: "[...] sendo demonstrada a existência de vínculos afetivos entre a criança e os adotantes, conforme regra constante no art. $28, \S 2^{\circ}$, do ECA, estes deverão prevalecer, tendo em vista o melhor interesse da criança”.

Para verificar a existência do vínculo afetivo são utilizados alguns parâmetros quanto à idade do bebê ou criança a ser adotada, ou seja, para bebês de até seis meses de idade entende-se que ainda não criaram vínculos afetivos com a família que estavam convivendo, fazendo com que a criança seja entregue para a próxima família da lista dos cadastrados. Em se tratando de crianças com mais de seis meses há entendimento que elas devem passar por avaliação interprofissional e que ao final seja emitido um laudo constatando se há a existência ou não de vínculo afetivo. Não se pode afirmar que este método utilizado é correto, tendo em vista que as crianças desde muito pequenas já reconhecem as pessoas que convivem com elas (MACIEL, 2007).

\section{APECTOS DISTINTIVOS DA ADOÇÃO LEGAL E ADOÇ̃̃O CONSENTIDA OU INTUITU PERSONAE}

A adoção legal se dá por meio de um processo judicial perante o juiz competente, ela possui algumas fases para então efetivar-se. Basicamente seria a preparação psicossocial e jurídica, habilitação, inscrição no cadastro e por fim a adoção se efetiva, primeira fase esta prevista no art. 50, $\S 3^{\circ}$, ECA qual prescreve o seguinte:

\begin{abstract}
Art. 50. A autoridade judiciária manterá, em cada comarca ou foro regional um registro de crianças e adolescentes em condições de serem adotados e outro de pessoas interessadas na adoção.

$\S 3^{\circ} \mathrm{A}$ inscrição de postulantes à adoção será precedida de um período de preparação psicossocial e jurídica, orientado pela equipe técnica da Justiça da Infância e da Juventude, preferencialmente com apoio dos técnicos responsáveis pela execução da política municipal de garantia do direito à convivência familiar.
\end{abstract}

Já em se tratando de adoção consentida ou intuitu personae, o legislador suprimiu sua aplicação, tendo em vista que não observa o procedimento de habilitação e o cadastro de adotantes, ou seja, a regra estabelecida pelo Estatuto da Criança e do Adolescente é que deverá ser observado o cadastro nacional de adotantes para evitar fraudes ou que a adoção ocorra e não atinja a sua finalidade. (ISHIDA, 2010). Diante disto, são notórias as diferenças existentes entre os procedimentos da adoção legal e da adoção consentida ou intuitu personae.

\subsection{CADASTRO DE ADOÇ̃̃O}

Os requerentes, estando habilitados passarão então a fazer parte do cadastro de adoção, que de acordo com Rosenvald é assunto que merece destaque. Conforme o art. 50 do ECA, também citado anteriormente deverá existir em cada Comarca e Juízo um cadastro de Crianças e Adolescentes que estão em condições de serem adotados e outro cadastro de pessoas que estão aptas a adotarem. Este cadastro deverá distin- 
guir as pessoas que residem no âmbito nacional e as que residem no estrangeiro, tendo em vista a diferença dos procedimentos e é claro o caráter prioritário da adoção nacional, como já citado no item anterior.

A existência deste cadastro é de grande importância e utilidade, como também ressalta Maciel (2007, p. 195): “A existência destes cadastros é bastante útil, pois facilita a apuração dos requisitos legais e facilita a compatibilidade entre adotante e adotando pela equipe interprofissional, o que tornará mais célere os processos de adoção".

Em relação ao cadastro Rossato (2009, p. 55) se manifesta: "Trata-se de um mecanismo que possibilita o cruzamento de dados e a rápida identificação de crianças ou adolescentes institucionalizados. Tal expediente permite, ainda, o intercâmbio de informações entre comarcas e regiões”. Ocorrendo este intercâmbio de que trata Rossato, poderão interessados de um lado do país adotar uma criança de local totalmente desconhecido, isto só se torna possível graças à correta alimentação dos dados no cadastro nacional (DIAS, 2009).

Em relação à manutenção e correta alimentação dos dados do cadastro nacional de adoção Rosenvald se manifesta: “A autoridade central de cada estado tem a responsabilidade de zelar pela manutenção e correta alimentação dos cadastros, com posterior comunicação à autoridade central federal”. O Ministério Público deverá fiscalizar a regularidade dos cadastros e a convocação dos interessados à adoção, tendo em vista o evidente interesse social de que trata esse assunto (ROSENVALD, 2010).

Cada Fórum possui um cadastro da Vara da Infância e da Juventude. Os cadastros estadual e nacional, além de sofrer a fiscalização do Ministério Público responsável pela Vara competente, também serão fis calizados pelo Conselho Nacional de Justiça (ISHIDA, 2010). O cadastro também tem por finalidade agilizar o processo de adoção, visando o melhor interesse da criança e do adolescente. De acordo com Dias (2009, p. 452) o Conselho Nacional de Adoção tem por objetivo:
[...] consolidar dados de todas as comarcas das unidades da federação referentes a crianças e adolescentes disponíveis para adoção, após o trânsito em julgado dos respectivos processos, bem como das pessoas dispostas a adotar. 0 sistema visa proporcionar menos burocracia e mais transparência aos processos de adoção.

A relação de crianças e adolescentes que estão em condições de serem adotados é feita pela equipe interprofissional da Vara da Infância e da Juventude, com base nos dados retirados de processos que estão em andamento, nos demais procedimentos em trâmite no juízo e nas informações repassadas pelos abrigos das crianças que estão sob sua responsabilidade (MACIEL, 2007).

Para a inclusão das crianças e adolescentes no cadastro nacional de adoção são adotados critérios e o que ocorre com maior frequência é o abandono por parte dos pais biológicos. Tal inclusão deve ocorrer no menor prazo possível, sendo aceita a demora somente nos casos em que a equipe interprofissional irá tentar localizar a família biológica (MACIEL, 2007).

Tem-se como regra geral que as famílias que não estejam cadastras não podem adotar, diante disto verifica-se que a adoção consentida ou intuitu personae não segue este procedimento, tendo em visa que os interessados não passaram pelo procedimento de habilitação e consequentemente não estão cadastrados.

Em pensamento contrário ao acima exposto Dias (2009, p. 452, grifo nosso) se manifesta:

De qualquer forma, ainda que haja a determinação de que sejam elaboradas as listas, não está escrito em nenhum lugar que só pode adotar quem está previamente inscrito, e que a adoção deve respeitar de forma estrita a ordem de inscrição. No entanto, passou a haver verdadeira idolatria á famigerada lista, a ponto de não se admitir qualquer transgressão a ela.

Novamente em crítica à observância restrita da ordem de inscrição e a obrigatoriedade de se analisar a lista Dias (2009, p. 452) declara:

Para que não haja burla à lista, a vigilância tem sido tão severa que nem mais se aceita trabalho voluntário junto a abrigos, com o receio de que lá as pesso- 
as compareçam para escolher alguma criança para adotar. Até parece que existe uma grande disputa, um enorme interesse pela adoção. Todos esquecem de que quem está lá depositado aguarda ansiosamente tornar-se filho de alguém.

De acordo com a manifestação de Dias (2009), é válido ressaltar que se deve priorizar o bem estar e o interesse da criança e do adolescente e não dar prioridade às listas ou ao cadastro de pretendentes. Também, se tem jurisprudência, sendo contrária a exigência de se observar rigorosamente o cadastro:

PODER JUDICIÁRIO TRIBUNAL DE JUSTIÇA. AGRAVO DE INSTRUMENTO No 723.670-4 DA $2^{\text {a }}$ VARA DE INFÂNCIA E JUVENTUDE, FAMÍLIA E ANEXOS DA COMARCA DE PARANAGUÁ. AGRAVANTE: MINISTRÉRIO PÚBLICO DO ESTADO DO PARANÁ. AGRAVADO: SEBASTIAO GONÇALVES DOS SANTOS E OUTRO. RELATOR: DES. ANTONIO LOYOLA VIEIRA. AGRAVO DE INSTRUMENTO AFERIÇAO DA PREVALÊNCIA ENTRE O CADASTRO DE ADOTANTES E A ADOÇAO INTUITU PERSONAE - APLICAÇAO DO PRINCÍPIO DO MELHOR INTERESSE DO MENOR - VEROSSÍMIL ESTABELECIMENTO DE VÍNCULO AFETIVO DAS MENORES COM O CASAL DE AGRAVADO - PERMANÊNCIA DAS CRIANÇAS COM O CASAL POR MAIS DE UM ANO - LISTA CRONOLÓGICA DE ADOÇAO NAO OBSERVADA - FATOS QUE, POR SI, NAO DENOTAM A PRÁTICA DE ILÍCITO RECURSO CONHECIDO E NAO PROVIDO. TRIBUNAL DE JUSTIÇA I - A observância do cadastro de adotantes vale dizer, a preferência das pessoas cronologicamente cadastradas para adotar determinada criança não é absoluta. [...]

Neste caso, a adoção consentida também se manteve, tendo em vista que foi observado novamente o princípio do melhor interesse do menor, e ainda a existência de vínculo afetivo entre o casal agravado e a criança. Como na jurisprudência citada anteriormente não há que se falar em regra absoluta referente à observância do cadastro.

Contrário ao pensamento citado acima Almeida (2002, p. 12) entende que o cadastro tem caráter obrigatório e absoluto, porém complementa: "São três as hipóteses de desconsideração do cadastro de adotantes, a saber: parentesco, afinidade, afetividade" (ALMEIDA, 2002).
Em relação à regra geral quanto ao cadastro a própria legislação em seu art. 50, § 13 do ECA autoriza à adoção por pessoas não cadastradas que prevê o seguinte:

$\S 13$. Somente poderá ser deferida adoção em favor de candidato domiciliado no Brasil não cadastrados previamente nos termos desta Lei quando:

I - se tratar de pedido de adoção unilateral;

II - for formulada por parente com o qual a criança ou adolescente mantenha vínculos de afinidade e afetividade;

III - oriundo o pedido de quem detém a tutela ou guarda legal de criança maior de 3 (três) anos ou adolescente, desde que o lapso de tempo de convivência comprove a fixação de laços de afinidade e afetividade, e não seja constatada a ocorrência de má-fé ou qualquer das situações previstas nos arts. 237 ou 238 desta Lei.

O juiz, tendo em vista tal previsão legal, deverá analisar o caso concreto, baseando-se nos princípios da proteção integral infanto-juvenil e a real vantagem do adotando e não deferir o pedido de adoção somente para as pessoas habilitadas e cadastradas. Analisando essa colocação verifica-se que é possível a adoção consentida ou intuitu personae. Nesta mesma perspectiva se manifesta Dias (2009, p. 453):

\begin{abstract}
A lei não limita a adoção a quem se encontra previamente inscrito, e muito menos impede a concessão de adoções em situações outras. A famigerada lista serve, tão-só, para organizar os pretendentes à adoção, isto é, para agilizar e facilitar a concessão da medida, e não para obstaculiza-la. Constituindo-se vínculo afetivo do pretendente com a criança, é perverso negar o pedido e entregar o adotando ao primeiro inscrito na lista. Tal postura desatende aos interesses prioritários de crianças e adolescentes, que gozam de especial proteção constitucional.
\end{abstract}

Desta forma, verifica-se que o que deve realmente ser analisado não é a ordem cronológica dos pretendentes a adoção, mas sim o bem estar da criança ou adolescente, pois não haveria motivo para tirar a criança dos cuidados de quem ela já se familiarizou para somente obedecer à lista.

A não observância do cadastro dos pretendentes à adoção, muitas vezes ocorre pela aplicabilidade do 
princípio do melhor interesse da criança e do adolescente, então acima de tudo deve ter prioridade o afeto construído entre adotante e adotado e não a aplicabilidade literal da lei.

\subsection{PROCESSO DE ADOÇÃO}

Quando os pretendentes à adoção cumprirem com os requisitos citados anteriormente, que são passar pelo procedimento de habilitação e após estarem inscritos no cadastro dos que estão aptos à adoção, poderão então entrar com o pedido de adoção.

A adoção ocorre por meio de processo judicial, independentemente se estiver tratando de criança, adolescente ou adulto, ficando totalmente proibido adoção por ato contratual ou por procuração. Neste sentido Dias (2009, p. 450) confirma o exposto: “A adoção, tanto de menores (ECA 47) como de maiores de 18 anos de idade (CC 1.623), só pode ocorrer mediante processo judicial".

O início do processo de adoção pode se dar por meio de pedido formulado pelo interessado ou por meio de advogado. Em relação a este assunto Ishida (2010, p. 78):

Entendemos que se aplica a seguinte regra: (1) o pedido de adoção pode ser formulado diretamente em cartório sem a necessidade de procurador (art.166, caput, do ECA); (2) havendo necessidade de procedimento contraditório, há necessidade de procurador ou a propositura pelo órgão do MP.

O ECA em seu art. 166 estabelece em quais hipóteses poderá ser feito o pedido diretamente em cartório:

Art. 166. Se os pais forem falecidos, tiverem sido destituídos ou suspensos do poder familiar, ou houverem aderido expressamente ao pedido de colocação em família substituta, este poderá ser formulado diretamente em cartório, em petição assinada pelos próprios requerentes, dispensada a assistência de advogado.

Realizado o pedido pelo requerente o juiz deverá nomear um advogado ou encaminhar para a Defensoria Pública, levando em consideração que a presença do profissional do direito é indispensável, conforme previsão legal no art. 133 da CF (ROSENVALD, 2010).
A petição inicial deverá conter os requisitos previstos no art. 165 do ECA que estabelece o seguinte:

Art. 165. São requisitos para a concessão de pedidos de colocação em família substituta:

I - qualificação completa do requerente e de seu eventual cônjuge, ou companheiro, com expressa anuência deste;

II - indicação de eventual parentesco do requerente e de seu cônjuge, ou companheiro, com a criança ou adolescente, especificando se tem ou não parente vivo;

III - qualificação completa da criança ou adolescente e de seus pais, se conhecidos;

IV - indicação do cartório onde foi inscrito nascimento, anexando, se possível, uma cópia da respectiva certidão;

V - declaração sobre a existência de bens, direitos ou rendimentos relativos à criança ou ao adolescente.

Parágrafo único. Em se tratando de adoção, observar-se-ão também os requisitos específicos.

A ação de adoção será processada na Vara da Família do domicílio do adotando quando o mesmo for pessoa maior de dezoito anos. Quando se tratar de adoção de criança e adolescente em situação de risco (conforme art. 98 do ECA) a competência para processar e julgar será da Vara da Infância e da Juventude, conforme prevê o art. 148, III, do ECA. Nesse sentido Ishida (2010, p. 283) manifesta-se: “Assim, a competência para o menor de dezoito anos é da Vara da Infância e da Juventude e para o maior de dezoito anos é da Vara de Família".

Ainda em se tratando de competência, o pedido deve ser ajuizado na comarca onde estiver o detentor da guarda do menor, como previsto na Súmula 383 do STJ: “A competência para processar e julgar as ações conexas de interesse de menor é, em princípio, do foro do domicílio do detentor de sua guarda”.

Durante o processo de adoção, o estágio de convivência continua sendo necessário. Quando se tratar de adoção de criança e adolescente, o juiz poderá dispensar o estágio em duas hipóteses: a) quando a criança for menor de um ano; b) qualquer que for a idade, mas que tenha a criação do vínculo afetivo (DIAS, 2009). 
0 pedido de adoção poderá ser cumulado com o pedido de destituição do poder familiar. Sendo deferida a adoção consequentemente levará a destituição do poder familiar. Neste sentido Dias (2009, p. 451) se manifesta: "Como a concessão da adoção implica, necessariamente, na perda do poder familiar, não ocasionando prejuízo a ausência do pleito da destituição, de forma expressa, tal pedido passou a ser considerado implícito".

Dias (2009, p. 451) complementa: "A jurisprudência, em primeiro momento, passou a admitir a cumulação das demandas de destituição e de adoção. Porém, formalismos de ordem processual não devem prevalecer em processos atinentes aos direito de crianças e adolescentes". Diante do exposto, verifica-se que não há necessidade da cumulação dos pedidos aqui citados, tendo em vista que o pedido de destituição se encontra de forma implícita no processo de adoção.

No andamento do processo, o juiz irá verificar se de fato a adoção apresenta vantagens e contempla reais benefícios ao adotando, não somente na esfera objetiva, mas também na subjetiva (ROSENVALD, 2010). Deverá também ser feito o estudo psicossocial do caso, sendo dispensável somente quando se tratar de adoção de adultos, conforme previsto no art. 167 do ECA.

No processo de adoção é imprescindível a participação do Ministério Público para manifestação e fiscalização, porém é válido ressaltar que o mesmo não possui legitimidade para propor a ação, ou seja, é vedada a sua atuação como órgão agente, o mesmo somente poderá atuar no processo como fiscal da lei (custus legis) (ROSENVALD, 2010).

Para compreender melhor a atuação do Ministério Público como fiscal da lei Ishida (2010, p. 419, grifo nosso) expõe: "O exercício então da função fiscal da lei vincula-se à legalidade do ato processual e da correta aplicação da lei ao caso concreto".

A obrigatoriedade de intervenção do Ministério Público possui previsão no art. 204 do ECA que nos contempla com o seguinte: "Art. 204. A falta de intervenção do Ministério Público acarreta a nulidade do feito, que será declarada de ofício pelo juiz ou a requerimento de qualquer interessado". Diante disto verifica-se que a ausência de participação ministerial nos processos de adoção gera nulidade processual. Nesse sentido é pacífica a jurisprudência:

\begin{abstract}
APELAÇÃO CÍVEL. AÇÃO DE ADOÇÃO CUMULAdA COM DESTITUIÇÃO DO PODER FAMILIAR. AUSÊNCIA DE MANIFESTAÇÃO DO MINISTÉRIO PÚBLICO INTERESSE DE INCAPAZ. OBRIGATORIEDADE DE INTERVENÇÃO DO MINISTÉRIO PÚBLICO (ART. 82, INCISOS I E II, E ART. 246, AMBOS DO CPC, E ART. 162, § 2․ ART. 201, INC. III, E ART. 204, ESTES DO ECA). INVALIDADE DECRETADA. SENTENÇA DESCONSTITUÍdA. (Apelação Cível No 70041924887, Sétima Câmara Cível, Tribunal de Justiça do RS, Relator: Jorge Luís Dall'Agnol, Julgado em 27/04/2011).
\end{abstract}

O Ministério Público pode atuar de forma livre e independente, nesse sentido Rosenvald (2010, p. 937) se manifesta: "[...] o Promotor de Justiça pode requerer a produção de provas e, inclusive, recorrer, mesmo que as partes da relação processual não interponham recurso voluntariamente". Na mesma perspectiva vejamos o teor da Súmula 99 do Superior Tribunal de Justiça: "O Ministério Público tem legitimidade para recorrer no processo em que oficiou como fiscal da lei, ainda que não haja recurso da parte".

Além da participação do Ministério Público também é necessária a participação dos genitores, ou seja, os pais biológicos deverão ser citados para fazerem parte do processo como litisconsorte necessário, contudo será dispensada a citação se ocorrer alguma das hipóteses em que for dispensado o consentimento dos genitores (DIAS, p. 451). Situação esta prevista no art. $45, \S 1^{\circ}$ do ECA que prevê o seguinte:

\begin{abstract}
Art. 45. A adoção depende do consentimento dos pais ou do representante legal do adotando.

$\S 1^{\circ}$. O consentimento será dispensado em relação à criança ou adolescente cujos pais sejam desconhecidos ou tenham sido destituídos do poder familiar.
\end{abstract}

A partir do momento em que o processo estiver apto para julgamento, os autos serão enviados para o juiz para prolação da sentença. A adoção somente se efetiva e produz efeitos a partir do trânsito em julgado da sentença judicial. Contudo, em relação a 
esta regra há uma exceção, qual seja, quando ocorre o falecimento do adotante no andamento do processo. Neste caso, a sentença judicial produzirá efeitos retroativos à data do óbito conforme elencado no $\S 7^{\circ}$ do art. 47 do ECA: "§ 7ํ. A adoção produz seus efeitos a partir do trânsito em julgado da sentença constitutiva, exceto na hipótese prevista no $\S 60$ do art. 42 desta Lei, caso em que terá força retroativa à data do óbito".

Porém para que produza efeitos retroativos deverá ter tido anteriormente inequívoca manifestação de vontade, conforme prevê o $\S 6^{\circ}$ do art. 42, do ECA: “§ 60 A adoção poderá ser deferida ao adotante que, após inequívoca manifestação de vontade, vier a falecer no curso do procedimento, antes de prolatada a sentença”.

Conforme prevê o art. 47 do ECA a sentença será inscrita mediante mandado judicial, no registro civil sendo vedado o fornecimento de certidão, ocorrendo o registro será automaticamente cancelado o registro original do adotado. Na certidão não poderá constar nenhuma observação em relação à origem do vínculo de filiação.

Diante do exposto até o presente momento, verifica-se que a adoção legal possui diversos requisitos para chegar à sentença constitutiva do direito de adoção, ou seja, os interessados deverão passar pelo procedimento de habilitação, deferido tal requerimento eles deverão passar a fazer parte do cadastro de adoção e quando tiver uma criança apta a ser adotada deverá então passar pelo processo de adoção, até ser deferido ou não o pedido.

Em se tratando de adoção consentida ou intuitu personae, há divergência quanto a sua aplicabilidade, uma vez que não observa todo o procedimento previsto em lei para realizar-se, contudo existem autores que entendem que o que deve ser priorizado é o vínculo afetivo existente entre os envolvidos e não a aplicação literal da lei, pois isso geraria muito mais sofrimento para a criança que já passou por momentos traumáticos em sua vida.

\section{ADOÇÃO CONSENTIDA E O RISCO NA FACILITAÇ̃̃O DO COMÉRCIO DE CRIANÇAS E ADOLESCENTES}

Neste tópico será feito um estudo referente à Convenção de Haia, tendo em vista que a mesma foi criada para evitar o tráfico e a venda de criança e adolescentes. No item referente à Convenção será analisado o que for pertinente ao assunto do presente trabalho, suas especificidades e os demais complexos normativos que envolvem o procedimento de adoção.

Ainda, será analisado o Projeto de Lei no 1212 de 2011 de autoria do Deputado Carlos Bezerra, que visa regulamentar a adoção consentida ou intuitu personae, o que será verificado adiante. E, por fim, serão abordados quais os benefícios e os malefícios que podem ser trazidos com a aceitação da adoção consentida ou intuitu personae, verificar se realmente este tipo de adoção pode influenciar no comércio de crianças e adolescentes, ou até mesmo no tráfico, este último principalmente no que concerne a adoção internacional.

\subsection{CONVENÇÃO DE HAIA}

O Brasil ratificou a Convenção Relativa à Proteção e Cooperação Internacional em Matéria de Adoção Internacional e, esta foi concluída na cidade de Haia, na Holanda no ano de 1993, depois foi aprovada pelo Decreto Legislativo, em seguida promulgada pelo Decreto $n^{\circ} 3.087 / 1999$, a mesma foi ratificada com a finalidade de evitar o tráfico e a venda de crianças e adolescentes (GRANATO, 2010).

0 texto da referida Convenção não admitia reservas, ou seja, o texto deveria ser aprovado na sua integralidade e foi o que ocorreu, por não contrariar o nosso sistema legislativo. No decorrer dos seus artigos a Convenção prevê os requisitos necessários para a concessão da adoção internacional e suas principais peculiaridades (GRANATO, 2010). Os objetivos da Convenção estão previstos em seu artigo $1^{\circ}$, que elenca o seguinte: 
A presente Convenção tem por objetivo: a) estabelecer garantias para que as adoções internacionais sejam feitas segundo o interesse superior da criança e com respeito aos direitos fundamentais que lhe reconhece o direito internacional; b) instaurar um sistema de cooperação entre os Estados Contratantes que assegure o respeito às mencionadas garantias e, em consequência, previna o sequestro, a venda ou o tráfico de crianças;

c) assegurar o reconhecimento nos Estados Contratantes das adoções realizadas segundo a Convenção.

A Constituição Federal também faz referência à adoção internacional em seu artigo $227, \S 5^{\circ}$ que dispõe o seguinte: "A adoção será assistida pelo Poder Público, na forma da lei, que estabelecerá casos e condições de sua efetivação por parte de estrangeiros".

Ademais, vale ressaltar que além da Convenção e da Constituição Federal preverem a adoção internacional, a mesma também é regulamentada pelo Estatuto da Criança e do Adolescente, como nas demais modalidades de adoção.

Entre os objetivos da Convenção de Haia é de suma importância citar a principal finalidade que é a de evitar o tráfico e a venda de crianças e adolescentes, como citado anteriormente e prevenir o sequestro das mesmas. Além disso, existem denúncias que argumentam que essa Convenção foi criada também para evitar a comercialização de órgãos do adotado, em relação a este ponto Granato (2010, p. 137) se opõe:

Não podemos silenciar sobre a infundada e gravíssima denúncia sobre o tráfico de órgãos infantis, que atingia e prejudicava a adoção internacional. Muito se escreveu sobre o assunto, mas de documento que goza de fidedignidade, o "Relatório submetido pela Agência de Divulgação dos Estados Unidos da América ao Relator Especial das Nações Unidas Sobre o Comércio de Crianças, a Prostituição e a Pornografia Infantis" [...], transcrevemos trechos conclusivos: Os especialistas em transplantes de órgãos concordam que seria impossível ocultar com êxito qualquer esquema clandestino orientado para o tráfico-de-órgãos-alimentado-pelo-homicídio. Devido ao número elevado de pessoas que precisam participar de um transplante de órgãos; a sofisticada tecnologia médica necessária para conduzir tais cirurgias, ao tempo extremamente curto em que os órgãos permanecem adequados ao transplante e a natureza abominável de tais atividades, tais operações não poderiam ser organizadas clandestinamente nem mantidas em segredo.

Diante disso, verifica-se que ficou apenas em denúncia e boatos referente ao tráfico de órgãos do adotado, não teve nenhum caso concreto verificado. É uma situação que seria quase impossível obter êxito, pois, para fazer um transplante de órgão é necessária tecnologia avançada e pessoas capacitadas para participar da cirurgia.

Com receio, verificou-se a necessidade da criação de legislação específica para assegurar os direitos das crianças e dos adolescentes, tendo em vista que os mesmos estavam sendo vítimas dos mais variados tipos de abusos. Diante de tais fatos, foi criada a Convenção para serem observados tais direitos inerente à criança e ao adolescente, sempre visando o melhor interesse do adotado.

A aplicação da Convenção de Haia é feita juntamente com o Estatuto da Criança e do adolescente, sendo considerada de aplicabilidade plena e devendo sempre ser observada, a fim de ser concretizada a adoção internacional. 0 art. 28 da Convenção preconiza o seguinte:

A Convenção não afetará nenhuma lei do Estado de origem que requeira que a adoção de uma criança residente habitualmente nesse Estado ocorra nesse Estado, ou que proíba a colocação da criança no Estado de acolhida ou seu deslocamento ao Estado de acolhida antes da adoção.

Com isso verifica-se que as leis nacionais foram mantidas e que se tem um pluralismo de normas regulamentando o procedimento de adoção internacional. De acordo com Maciel (2007, p. 225):

A Convenção de Haia foi elaborada no sentido de sanar os problemas relacionados com corrupção, busca de lucro com a adoção, falsificação de registros de nascimento, compra de crianças dos pais biológicos, entre outros, além de tentar uma regulamentação uniforme no que concerne aos requisitos para conhecimento das adoções pelos diversos países que recebiam as crianças adotadas. 
Com a cooperação entre os Estados contratantes o objetivo é dificultar o tráfico e a venda de crianças e adolescentes, ainda diminuir os demais crimes relacionados. Para atingir tal finalidade, a Convenção de Haia elenca algumas condições, dentre elas, é válido citar, o consentimento dos pais biológicos, este que deve ocorrer de forma voluntária e sem qualquer pagamento, conforme preconiza o art. $4^{\circ}$, para evitar o comércio das crianças ou adolescentes, entre as condições também está o consentimento do adotando, previsto no mesmo artigo.

A Convenção prevê também a proibição de contato entre os pais biológicos e os pais adotivos, conforme consta no art. 29, para evitar qualquer tipo de "negociação" do adotando. Prevê ainda, que a criança seja considerada adotável e, que os futuros pais sejam considerados aptos a adotar de acordo com 0 art. $5^{\circ}$ da Convenção, dentre outras condições elencadas.

A adoção internacional é aplicada de forma subsidiária, ou seja, deverão ser esgotados todos os recursos para manter o adotando em território de sua origem, conforme previsão legal no $\S 10$ do artigo 50 do Estatuto da Criança e do Adolescente que elucida o seguinte:

$\S 10$. A adoção internacional somente será deferida se, após consulta ao cadastro de pessoas ou casais habilitados à adoção, mantido pela Justiça da Infância e da Juventude na comarca, bem como aos cadastros estadual e nacional referidos no § 5deste artigo, não for encontrado interessado com residência permanente no Brasil.

Nesse sentido, Maciel (2007, p. 227) “Deve-se tentar manter a criança em seu país de origem, pois tem ela o direito de ser mantida em contato com suas raízes, seus hábitos e costumes, sua cultura”. Portanto, a adoção internacional será aplicada de forma excepcional, tendo em vista que para a mesma ser deferida deverá observar diversos requisitos.

Corroborando, Granato (2010, p. 128):

Com a nova lei, a adoção internacional, que já era bastante problemática, se tornou quase impossível. É o que se depreende da entrevista dada pela ex - desembargadora do Rio Grande do Sul, Dra. Maria Berenice
Dias e publicada no Caderno Feminino do jornal O Estado de São Paulo, do dia 16.08.2009, às p. 14 e 15, res pondendo à pergunta da entrevistadora (E em relação aos casos de adotantes que vivem no exterior?)“Parece que ficou mais complicado ainda. A adoção internacional, de fato, carecia de regulamentação. Mas fo tão exaustivamente disciplinada, impondo-se tantos entraves e exigências, que dificilmente alguém conseguirá obtê-la. Até porque o laudo de habilitação tem validade de, no máximo, um ano. E como só se dará a adoção internacional depois de esgotadas todas as possibilidades de colocação em família substituta brasileira, após consulta aos cadastros nacionais, parece que a intenção foi vetá-la”.

Deste modo, será quase impossível se obter a adoção internacional, tendo em vista as peculiaridades e exigências trazidas pela Convenção de Haia e as demais regulamentações.

Por conseguinte, verifica-se que a preocupação do legislador foi elaborar normas para impedir os mais diversos crimes, envolvendo as crianças e os adolescentes que estavam sendo adotados, pois o que realmente ocorria era uma simulação de uma adoção. Em relação ao tráfico e a venda dos adotados, a maior preocupação incidiu sobre a adoção internacional, tendo em vista que a criança se deslocava para outro país, desligando-se totalmente de suas origens e onde a legislação brasileira não poderia intervir.

\subsection{PROJETO DE LEI № 1212/2011}

A Lei 12.010 de 2009 acrescentou o parágrafo 13 ao artigo 50 do Estatuto da Criança e do Adolescente, regulamentando de forma taxativa os casos em que será deferida a adoção para domiciliados no Brasil, os quais não estejam cadastrados, artigo este já mencionado anteriormente. A referida Lei não trouxe consigo a previsão da adoção intuitu personae, mas não é em razão disso que acabam as expectativas do reconhecimento dela. Vale ressaltar que não existe previsão legal expressa, contudo, também não há vedação concludente (DIAS, 2009). Neste sentido, Dias (2009, p. 445) se manifesta: “A omissão do legislador, em sede de adoção, não significa que não existe tal possibilidade". 
Em 2003, foi apresentado um Projeto de Lei $n^{\circ}$ 1756, de autoria do Deputado Federal João Matos que em 2005 foi substituído pelo Projeto de Lei no 6222, e em seguida foi transformado na Lei Ordinária $n^{\circ}$ 12.010 de 2009, o primeiro previa expressamente a adoção intuitu personae como pode ser verificado a seguir (GRANATO, 2010).

\section{Capítulo IV}

DAS HIPÓTESES DE DISPENSA DE PRÉVIO CADASTRAMENTO

Art. $8^{\circ}$ Somente poderá ser deferida adoção em favor de candidato domiciliado no Brasil não inscrito no cadastro a que alude o art. $7^{\circ}$ desta Lei quando se tratar de pedido de adoção unilateral, ou formulada por parente próximo, ou com adesão expressa dos genitores, ou quando se tratar de

guarda fática, em que o lapso de tempo de convivência comprove a fixação de laços de afinidade e afetividade. $\S 1^{\circ} \mathrm{A}$ adesão expressa dos genitores, ou de um deles, deverá ser devidamente justificada, podendo a Autoridade Judiciária determinar dilação probatória, de ofício, para comprovação do que for afirmado. [...]

Seção IV

ADOÇÃO COM DISPENSA DE PRÉVIO CADASTRAMENTO

Art. 41. Somente serão admitidos pedidos de adoção com dispensa de prévio cadastramento quando o requerente, além dos requisitos previstos nos incisos I a IV do artigo $n^{0} 29$ desta Lei, comprovar na petição inicial que se inclui em uma das hipóteses do artigo $8^{\circ}$, também desta Lei.

$\S 1^{0}$ Nos casos de adoção unilateral, de parente próximo ou com adesão expressa, será obrigatória a realização de audiência, na presença da Autoridade Judiciária e do Promotor de Justiça, para oitiva dos genitores, salvo se falecidos, decaídos do Poder Familiar, desconhecidos ou declarados judicialmente ausentes, ocasião em que deverão ser advertidos da irrevogabilidade da medida. Se os genitores forem menores de dezoito anos, ainda que assistidos ou representados pelos pais, a Autoridade Judiciária lhes dará curador especial, consignando no termo que a concordância se dá em relação à adoção e não exclusivamente para aquele pedido que está sendo processado.

Com essa alteração seria excluída, de forma definitiva, a polêmica envolvendo o prévio cadastro no processo de adoção. Porém com a promulgação da Lei $n^{0} 12.010$ de 2009, verificou-se que ela não substitui o Projeto de Lei nº 6222 de 2005, pois a mesma não prevê a adoção intuitu personae (GRANATO, 2010).

Contudo, foi criado um novo Projeto de Lei $n^{0}$ 1212/2011 este de autoria do Deputado Carlos Bezerra, o qual visa acrescentar dispositivo à Lei $n^{0} 8.069$ de 1990, conhecida como Estatuto da Criança e do Adolescente. 0 Projeto tem por finalidade regulamentar a permissão da adoção consentida ou intuitu personae, considerando a mesma legal quando verificada as seguintes situações, conforme previsão no artigo $1^{\circ}$ do Projeto:

Art. $1^{0}$ Esta lei acrescenta o art. 50-A ao Estatuto da Criança e do Adolescente, para autorizar a adoção por parte de quem recebeu dos genitores, de forma expressa, criança ou adolescente para adoção, ou tenha acolhido criança em situação de perigo em razão de abandono. (BEZERRA, 2011, on-line).

Dessa forma, nas situações em que os genitores de forma expressa autorizam a adoção e nos casos em que tenham acolhido a criança em situação de perigo ou abandono, a adoção seria considerada legal e possível.

Como citado anteriormente o Projeto de Lei $n^{0}$ 1212/2011, tem por finalidade acrescentar ao Estatuto da Criança e do Adolescente o artigo 50-A, que vigoraria nos seguintes termos:

Art. 50A. Serão adotados, independentemente da ordem no registro de criança e adolescentes em condições de serem adotadas ou no registro de pessoas interessadas na adoção, aqueles que, atendendo às demais condições legais, especialmente as previstas nos parágrafos do art. 28, no art. 29 e no art. 43:

I - tenham sido expressamente doados pelo genitor ou genitores conhecidos;

II - tenham sido acolhidos, em situação de perigo devido a abandono, por pessoas que venham a se interessar pela adoção.

Portanto, caso o Projeto de Lei for aprovado, a adoção deverá ser deferida nos casos citados acima, sendo desnecessária a observância restrita da ordem de inscrição, pois, a observância a ela impede que ocorra a adoção em situações peculiares, deixando de analisar o princípio do melhor interesse do 
adotando, tudo em conformidade com a justificativa apresentada no Projeto.

Dentre as situações peculiares consta na justificativa do Projeto os casos de adoção à brasileira, esta vedada pelo nosso ordenamento jurídico e também os casos de acolhimento de crianças abandonadas ou em situação de perigo, esta última situação é analisada pelo prisma de uma família estranha acolher a criança, sem nunca ter pensado em adotar, porém passou a pensar após o acontecido. Esse seria um dos casos que caberia o deferimento da adoção, contudo seria indeferido caso o Juiz se atente restritamente para o previsto no art. 50 do Estatuto da Criança e do Adolescente.

0 projeto também justifica sua criação, levando em consideração o previsto nos artigo 28 e 43 do ECA que preconizam o seguinte:

Art. 28. A colocação em família substituta far-se-á mediante guarda, tutela ou adoção, independentemente da situação jurídica da criança ou adolescente, nos termos desta Lei.

$\S 1^{0}$ Sempre que possível, a criança ou adolescente deverá ser previamente ouvido e a sua opinião devidamente considerada.

$\S 2^{\circ} \mathrm{Na}$ apreciação do pedido levar-se-á em conta o grau de parentesco e a relação de afinidade ou de afetividade, a fim de evitar ou minorar as consequências decorrentes da medida.

Art. 43. A adoção será deferida quando apresentar reais vantagens para o adotando e fundar-se em motivos legítimos.

Então, para que o juiz defira ou não o pedido de adoção, levar-se-á em consideração o grau de parentesco, a afinidade, a afetividade e as reais vantagens para o adotando, dentre outros requisitos e no restante seguirá o procedimento normal da adoção, somente não será observado o requisito cadastral.

Neste sentido, há jurisprudência:

APELAÇÃO CÍVEL. ESTATUTO DA CRIANÇA E DO ADOLESCENTE. ADOÇÃO INTUITU PERSONAE. PEDIDO JURIDICAMENTE POSSÍVEL, CONFORME JURISPRUDÊNCIA PACÍFICA DO TJRN E DO STJ. INAPLICABILIDADE DA TEORIA DA CAUSA MADURA, DADA A INEXISTÊNCIA DE ELEMENTOS IMPRESCINDÍVEIS AO EXAME DO MERITUM CAUSAE. SENTENÇA ANULADA.
RECURSO CONHECIDO E PROVIDO. AGRAVO INSTRUMENTO. DIREITO DA CRIANÇA E DO ADOLESCENTE. AÇÃO DE ADOÇÃO COM PEDIDO DE GUARDA PROVISÓRIA. DECISUM QUE DEFERIU A GUARDA PROVISÓRIA A RECORRIDA COM FUNDAMENTO NO ARTIGO 28 C/C ARTIGO 33, § $1^{\circ}$, da Lei 8.060/90-ECA. ADOÇÃO INTUITU PERSONAE. PERMANÊNCIA DA CRIANÇA DURANTE OS PRIMEIROS DIAS DE VIDA COM A PRETENSA ADOTANTE. CONVIVÊNCIA FAMILIAR QUE DEVE SER ASSEGURADA À INFANTE. PRESERVAÇÃO DO VÍNCULO AFETIVO E FAMILIAR DA MENOR. PRECEDENTES DO STJ E DESTA CORTE DE JUSTIÇA. CONHECIMENTO E DESPROVIMENTO DO RECURSO.ESTATUTO DA CRIANÇA E DO ADOLESCENTE $2833 \S 1^{\circ}$ 8.060 ECA - A observância do cadastro de adotantes, não é absoluta, isto porque é possível excepcionar este regramento em atenção ao princípio do melhor interesse do menor, considerando a hipótese de existir vínculo afetivo entre a criança e o pretendente à adoção, ainda que este não se encontre sequer cadastrado no referido registro; II - Existência de estudo psicológico preliminar que sinalizou positivamente, no sentido de que a menor deve permanecer com a recorrida. $\mathrm{Al}-2^{\mathrm{a}}$ CC - RELA. DESA. MARIA ZENEIDE BEZERRA - DJ DE 19/05/2010;CC (41447 RN 2010.004144-7, Relator: Juíza Sulamita Bezerra Pacheco (Convocada), Data de Julgamento: 26/08/2010, 3ª Câmara Cível).

Os tribunais, quase de forma unânime e até não tendo legislação expressa, prevendo esta modalidade de adoção, estão deferindo a adoção consentida, sempre primando pelo melhor interesse do menor $\mathrm{e}$ analisando o vínculo afetivo existente entre a criança e os pretendentes à adoção.

\subsection{BENEFÍCIOS E MALEFí́IIOS TRAZIDOS COM A ADOÇ̃̃o CONSENTIDA OU INTUITU PERSONAE}

A adoção consentida ou intuitu personae não possui previsão legal, como já citado diversas vezes, porém existem entendimentos jurisprudências a favor de sua aplicabilidade, como também existem os tribunais que são contra esta modalidade, tendo em vista que não observa o requisito de cadastro de adotantes mantido em cada comarca ou foro.

Contrário à adoção consentida ou intuitu personae, Almeida (2002, p. 12) expõe: “[...] a adoção 'intuitu personae, há que ser tratada e combatida de forma 
absolutamente rápida, precisa e rigorosa, impedindo-se a formação dos vínculos."

Contudo, os tribunais que optaram pelo deferimento, motivam sua decisão no princípio do melhor interesse do menor, a verificação de existência de vínculo afetivo e, que a observância da ordem preferencial do cadastro não é considerada uma regra de ordem absoluta, portanto a adoção consentida deve ser aceita.

Há posicionamentos diversos entre os doutrinadores, alguns defendem a possibilidade da adoção consentida ou intuitu personae, já outros a repudiam, tendo em vista que a genitora faz a escolha para quem deseja adotar seu filho e com isso não é observado o cadastro de adotantes, alguns ainda argumentam que os pais não são capacitados para fazerem essa escolha e sim, deverá ser feito pelo Poder Judiciário.

Nesse sentido, decisão jurisprudencial:

\begin{abstract}
APELAÇÃO CÍVEL. AÇÃO DE DESTITUIÇÃO DO PODER FAMILIAR. ENTREGA DA FILHA A CASAL ESTRANHO. ADOÇÃO INTUITU PERSONAE. ABANDONO MATERIAL E EMOCIONAL EVIDENCIADOS. EXPOSIÇÃO DA CRIANÇA A SITUAÇÃO DE RISCO. PREVALÊNCIA DOS INTERESSES DA INFANTE. RECURSO CONHECIDO E NÃO PROVIDO. O Estatuto da Criança e do Adolescente jamais conferiu aos pais qualquer direito de escolha em relação às pessoas que irão adotar seus filhos, pois esta é uma prerrogativa exclusiva da Justiça da Infância e da Juventude. Estatuto da Criança e do Adolescente.

(349016 SC 2011.034901-6, Relator: Victor Ferreira, Data de Julgamento: 29/08/2011, Quarta Câmara de Direito Civil, Data de Publicação: Apelação Cível n. , de Urussanga).
\end{abstract}

Esta decisão justifica-se no sentido de que os pais não podem escolher quem irá adotar seus filhos, considerou que a genitora agiu de forma imprudente entregando o filho a um casal estranho, e, portanto perdeu o poder familiar e os pretendentes à adoção não puderam ficar com a criança, tendo em vista que quem proferiu a decisão entendeu que ainda não havia vínculo afetivo formado entre eles, por se tratar de uma criança recém-nascida (JUS BRASIL, on-line) ${ }^{1}$.

1.Disponível em: <http://www.jusbrasil.com.br/jurisprudencia/20301181/ apelacao-civel-ac-349016-sc-2011034901-6-tjsc>. Acesso em: 28 out. 2012.
A pessoa que entrega o filho para a adoção, normalmente recebe críticas e julgamentos e não compaixão, apreço e compreensão. Em um artigo publicado por Maria Berenice Dias, a mesma afirma o seguinte: "Aliás, dar um filho à adoção é o maior gesto de amor que existe. Sabendo que não poderá criá-lo, renunciar ao filho para assegurar-lhe uma vida melhor que a sua é atitude que só o amor justifica" (DIAS, on-line) ${ }^{2}$.

Nesse sentido, Maciel (2007, p. 220) acrescenta:

\begin{abstract}
Temos que deixar de encarar os pais que optam por entregar seu filho em adoção como pessoas que cometem alguma espécie de crime. A ação destes pais merece compreensão, pois, se verificam que não terão condições de cuidar da criança, ao optarem pela entrega, estão agindo com todo amor e carinho por seu filho, buscando aquilo que entendem melhor para ele.
\end{abstract}

Esta modalidade de adoção traz consigo alguns benefícios, dentre eles é válido mencionar a maior celeridade no processo de adoção, tendo em vista que normalmente os adotantes já estão sob a posse de fato da criança e, portanto, resta somente regularizar a situação. Já no processo de adoção legal, os adotantes devem passar pelo procedimento de habilitação, para em seguida fazer parte do cadastro nacional e então aguardar a chegada de uma criança adotável (DIAS, 2009).

Nesse sentido, Kusano (2006, p. 75) se manifesta:

A morosidade no processo de adoção, na destituição do poder familiar e a rejeição de crianças com mais de três anos de idade são alguns dos fatores que fazem com que milhares de crianças passem suas infâncias em orfanatos, sem receber a atenção e o carinho de que precisam, o que lhe acarreta inúmeros malefícios.

Portanto, para alguns doutrinadores a adoção consentida é viável, por ser mais célere e trazer menos consequências ao menor, tendo em vista que este não ficará institucionalizado, aguardando a colocação em uma família substituta.

A adoção consentida também é vista como solução para alguns problemas, visto que esse instituto acelera o andamento do processo de adoção, prima pelo 2. Disponível em: <http://www.mbdias.com.br/hartigos.aspx?28,8>. Acesso em: 28 out. 2012. 
melhor interesse do menor, pela dignidade da pessoa humana e ainda o menor poderá manter contato com a família de origem.

Já para outros doutrinadores esta modalidade pode trazer mais malefícios do que benefícios. Entre as argumentações contrárias a esta possibilidade, cita-se a escolha feita pelos genitores, pois não tem como ter certeza se realmente os adotantes possuem condições necessárias para criar um filho, ou seja, exercer de fato a paternidade. Caso no andamento do processo isto seja verificado deverá ser retirada a criança da guarda dos pretendentes à adoção, destiná-la para uma instituição e após ser encaminhada para outra família que esteja apta para a adoção e que esteja entre os cadastrados (MACIEL, 2007).

A situação citada anteriormente é analisada como um malefício, tendo em vista que a criança já está com os adotantes e será retirada destes, para posteriormente ser encaminhada a uma família que esteja com o seu nome incluído no cadastro nacional de adoção.

Outro argumento apresentado contra a adoção consentida ou intuitu personae, refere-se ao desrespeito ao cadastro, já que o mesmo é considerado por muitos de caráter obrigatório. Justifica-se esse argumento da seguinte forma, as pessoas que constam no cadastro são consideradas aptas a exercer a paternidade, e caso fosse concedida a adoção a quem não esteja cadastrado, àqueles deverão esperar por tempo superior ao normal à chegada de uma criança (MACIEL, 2007).

Em relação a não observância do cadastro Granato (2010, p. 144) se manifesta:

É certo que todo um sistema está em jogo, montado principalmente para evitar que alguém leve alguma vantagem indevida com a adoção, o que faz com que o poder do Estado se sobreponha ao poder familiar dos pais, cabendo àquele e não a estes dizer quem deve adotar a criança.

Além desses argumentos contrários a este instituto, Almeida (2002, p. 13) acrescenta:

Outro fator a ser sopesado, é que, a grande possibilidade que os pais biológicos, sabedores onde e com quem está a criança, seja pelo breve contato que ti- veram com os adotantes quando da entrega, seja pelo intermediário, passem a achacar a família substituta, realizando pedidos de contato com o filho ou mesmo objetivando "auxílio" financeiro, gerando intranquilidade e instabilidade naquela família, e de forma inexorável, refletindo negativamente na criança. [...] Portanto, tais ações indevidas são de todo reprováveis e só apresentam desvantagens de sua escolha, já que representam incerteza jurídica, risco de procura pela família natural, dubiedade da situação e insegurança fática acerca da permanência da adoção.

Outro argumento desfavorável está relacionado ao tema principal do presente trabalho, ou seja, a entrega da criança pelos pais poderia de alguma forma estar pactuando com o comércio/tráfico de uma criança, visto que os adotantes podem ter oferecido algum dinheiro ou qualquer outro tipo de favorecimento para os pais, em troca de um filho, violando com isso a dignidade da pessoa humana (MACIEL, 2007).

Há divergência nesse ponto entre os doutrinadores, alguns entendem não dever ser generalizado esse entendimento, de que a entrega da criança nos casos de adoção consentida pode compactuar com a venda do filho, já outros entendem que sim, ou seja, pode levar à comercialização de crianças.

Maciel (2007, p. 221), posicionando-se favoravelmente a adoção consentida, se manifesta:

Por certo que a troca de uma criança por dinheiro ou algum outro benefício é fato que causa grande repulsa e também somos contrários a ela, mas é certo que nem sempre isso irá ocorrer. Não se deve ter a ideia de má-fé envolvendo todos os atos que são praticados envolvendo a entrega de uma criança, sendo este um pré-conceito dos profissionais do direito. Existindo alguma suspeita que tal situação possa ter ocorrido, deverá ser investigada no transcorrer do processo de adoção, sendo tomadas as medidas legais cabíveis, caso seja ele comprovado.

Portanto, verifica-se que autor acredita que não se deve generalizar, não se pode envolver a ideia de má-fé em todos os casos de adoção consentida, porém caso exista esta suspeita, deverá ser investigada.

Contudo, não são todos que se posicionam dessa forma, podendo-se citar Almeida (2002, p. 13), que expõe o seguinte: 
A entrega direta incentiva o tráfico e intermediação de crianças, incrementando um dos mais reprováveis atos de ganho de dinheiro, o que é combatido pelo Estatuto em seus arts. 238 e 239 e sofre severa restrição no regramento internacional.

Em hipótese nenhuma será permitido que os genitores troquem seus filhos por favores econômicos, pois estariam violando o Princípio Constitucional da Dignidade da Pessoa Humana e, caso fique comprovada esta situação, os pais responderão pelos crimes dos artigos 238 e 239 do Estatuto da Criança e do Adolescente como citado anteriormente, que prescreve o seguinte:

Art. 238. Prometer ou efetivar a entrega de filho ou pupilo a terceiro, mediante paga ou recompensa:

Pena - reclusão de um a quatro anos, e multa. Parágrafo único. Incide nas mesmas penas quem oferece ou efetiva a paga ou recompensa.

Art. 239. Promover ou auxiliar a efetivação de ato destinado ao envio de criança ou adolescente para o exterior com inobservância das formalidades legais ou com o fito de obter lucro:

Pena - reclusão de quatro a seis anos, e multa.

Parágrafo único. Se há emprego de violência, grave ameaça ou fraude:

Pena - reclusão, de 6 (seis) a 8 (oito) anos, além da pena correspondente à violência.

Verifica-se, analisando as citações, de pronto a divergência entre os operadores do direito quanto à possibilidade de a adoção consentida ou intuito personae representar um risco na facilitação do comércio de crianças e adolescentes.

Contudo, a jurisprudência também se manifesta favorável à adoção consentida, conforme segue:

RECURSO ESPECIAL - AFERIÇÃO DA PREVALÊNCIA ENTRE O CADASTRO DE ADOTANTES E A ADOÇÃO INTUITU PERSONAE - APLICAÇÃO DO PRINCÍPIO DO MELHOR INTERESSE DO MENOR - VEROSSÍMIL ESTABELECIMENTO DE VÍNCULO AFETIVO DA MENOR COM O CASAL DE ADOTANTES NÃO CADASTRADOS - PERMANÊNCIA DA CRIANÇA DURANTE OS PRIMEIROS OITO MESES DE VIDA - TRÁFICO DE CRIANÇA - NÃO VERIFICAÇÃO - FATOS QUE, POR SI, NÃO DENOTAM A PRÁTICA DE ILÍCITO - RECURSO ESPECIAL PROVIDO. I - A observância do cadastro de adotantes, vale dizer, a preferência das pessoas cronologicamente cadastradas para adotar determinada criança não é absoluta. Excepciona-se tal regramento, em observância ao princípio do melhor interesse do menor, basilar e norteador de todo o sistema protecionista do menor, na hipótese de existir vínculo afetivo entre a criança e o pretendente à adoção, ainda que este não se encontre sequer cadastrado no referido registro; II - $E$ incontroverso nos autos, de acordo com a moldura fática delineada pelas Instâncias ordinárias, que esta criança esteve sob a guarda dos ora recorrentes, de forma ininterrupta, durante os primeiros oito meses de vida, por conta de uma decisão judicial prolatada pelo i. desembargador-relator que, como visto, conferiu efeito suspensivo ao Agravo de Instrumento n. 1.0672.08.277590-5/001. Em se tratando de ações que objetivam a adoção de menores, nas quais há a primazia do interesse destes, os efeitos de uma decisão judicial possuem o potencial de consolidar uma situação jurídica, muitas vezes, incontornável, tal como o estabelecimento de vínculo afetivo; III - Em razão do convívio diário da menor com o casal, ora recorrente, durante seus primeiros oito meses de vida, propiciado por decisão judicial, ressalte-se, verifica-se, nos termos do estudo psicossocial, o estreitamento da relação de maternidade (até mesmo com o essencial aleitamento da criança) e de paternidade e o consequente vínculo de afetividade; IV - Mostra-se insubsistente o fundamento adotado pelo Tribunal de origem no sentido de que a criança, por contar com menos de um ano de idade, e, considerando a formalidade do cadastro, poderia ser afastada deste casal adotante, pois não levou em consideração o único e imprescindível critério a ser observado, qual seja, a existência de vínculo de afetividade da infante com o casal adotante, que, como visto, insinua-se presente; $\mathrm{V}$ - $\mathrm{O}$ argumento de que a vida pregressa da mãe biológica, dependente química e com vida desregrada, tendo já concedido, anteriormente, outro filho à adoção, não pode conduzir, por si só, à conclusão de que houvera, na espécie, venda, tráfico da criança adotanda. Ademais, o verossímil estabelecimento do vínculo de afetividade da menor com os recorrentes deve sobrepor-se, no caso dos autos, aos fatos que, por si só, não consubstanciam o inaceitável tráfico de criança; VI - Recurso Especial provido. (1172067 MG 2009/0052962-4, Relator: Ministro MASSAMI UYEDA, Data de Julgamento: 18/03/2010, T3 - TERCEIRA TURMA, Data de Publicação: DJe 14/04/2010).

Nesta decisão, o julgador entende, não verificada a existência de venda, tráfico de crianças, pois, em primeira instância, para chegar a essa conclusão foi analisada a vida pregressa da genitora, por ela ser dependente química e por levar uma vida desregrada, 
isso não pode conduzir a este entendimento. Portanto, neste caso não há que se falar em venda de criança, mas sim o que deve se sobrepor é a análise da criação do vínculo afetivo e primar pelo princípio do melhor interesse do menor, estes no caso em tela reconhecidos.

O entendimento majoritário é que a adoção consentida ou intuitu personae deve ser reconhecida e não analisar somente o cadastro nacional, pois este nada mais é que um instrumento que pode agilizar os demais processos de adoção.

Nesse sentido Maciel (2007, p. 222) se manifesta: “Não devemos nos posicionar contra com a alegação de que está sendo violada a regra que obriga o respeito ao cadastro".

Dias (2009, p. 453), complementando, expõe:

Constituindo vínculo afetivo do pretendente com a criança, é perverso negar o pedido e entregar o adotando ao primeiro inscrito da lista. Tal postura desatende aos interesses prioritários de crianças e adolescentes, que gozam de especial proteção constitucional.

Com isso, verifica-se que estando presente o vínculo afetivo entre os pretendentes a adoção e o menor, e que, a decisão vise atender o melhor interesse do menor, a adoção consentida deverá ser deferida, pois não há que se falar em comércio de crianças e adolescentes, mas sim, analisar os benefícios que podem ser trazidos com a previsão legal da adoção consentida, como por exemplo, a celeridade processual e o procedimento menos doloroso para a criança.

Portanto, para finalizar deverá ser aguardada a análise do Projeto de Lei n 1212/2011, para que seja aprovado e que regulamente a adoção consentida ou intuitu personae, pois caso aprovado, irá evitar fraudes à lei e respeitar o melhor interesse do menor e a dignidade da pessoa humana.

\section{CONCLUSÃO}

Neste artigo, procurou-se esclarecer como funciona o procedimento de colocação em família substitu- ta, dentre as modalidades foi estudado o instituto da adoção e suas peculiaridades. Um dos objetivos foi analisar o processo de adoção legal, fazendo uma comparação com o instituto da adoção consentida também denominada adoção intuitu personae e sua aplicabilidade no ordenamento jurídico brasileiro, tendo em vista que ela não possui previsão legal, contando apenas com decisões que optaram pelo seu deferimento.

A finalidade deste estudo foi analisar se a adoção consentida poderia trazer algum risco na facilitação do comércio de crianças e adolescentes, tendo em vista que os pais fazem a escolha dos adotantes, verificando se esta escolha poderia ser feita em troca de dinheiro ou qualquer outro tipo de favorecimento.

Diante do exposto no trabalho, verificou-se a grande divergência sobre a aceitação da adoção consentida e sobre a possibilidade da mesma incentivar o comércio de crianças e adolescentes. A maioria dos doutrinadores e a maioria das decisões jurisprudenciais são a favor de sua aplicação, considerando que a melhor forma de atender o princípio do melhor interesse do menor e o princípio da dignidade da pessoa humana, será optando pelo seu deferimento. A maioria das decisões que deferiram a adoção consentida também se baseou no vínculo de afetividade já existente entre os pretendentes e a criança.

Portanto, a má-fé, envolvendo os pais biológicos e os pretendentes à adoção é considerada uma exceção, não deverá ser generalizada. Diante disso, verifica-se que a adoção intuiu personae não é um risco para o comércio de crianças e adolescentes, pois a escolha feita pela mãe é um gesto de amor e esta escolha deve ser considerada quanto for proferida a decisão.

Assim, o reconhecimento da adoção consentida no direito pátrio seria a melhor maneira de combater as irregularidades que ocorrem no âmbito da adoção, tendo em vista, que alguns não procuram o judiciário e com isso acabam praticando a adoção à brasileira, esta vedada pelo nosso ordenamento. Então, bastaria o consentimento expresso dos pais para que a adoção consentida fosse possível e depois seguiria todo o trâmite normal do processo de adoção legal. 
Verifica-se com o estudo que a adoção consentida permite um processo mais célere e menos doloroso ao menor, pois, bastaria o consentimento dos pais biológicos que a adoção poderia se perfectibilizar, não causando maiores danos e traumas à criança. Conclui-se, portanto, que a adoção esta sendo reconhecida pela maioria dos tribunais e está sendo aceita pela maioria dos doutrinadores, pois, ela não possui previsão legal, mas também não existe vedação expressa sobre sua aplicabilidade.

A rigorosa observância do cadastro previsto no art. 50 do Estatuto da Criança e do Adolescente, é de grande valia, porém não deve ser observado como uma regra absoluta, como verificada pelas decisões citadas na presente obra, portanto sua aplicabilidade deve ser flexibilizada pelos operadores do direito, garantindo assim a observância dos princípios constitucionais do melhor interesse do menor e da dignidade da pessoa humana.

Por fim, resta aguardar o trâmite do Projeto de Lei $n^{0} 1212 / 2011$, para que o seja aprovado e passe a vigorar em nosso ordenamento, para regularizar a situação da adoção consentida ou intuitu personae. No entanto desde janeiro de 2015, o Projeto encontra-se arquivado na Mesa Diretora da Câmara dos Deputados, nos termos do art. 105 do Regimento Interno daquele órgão.

\section{REFERÊNCIAS}

ALMEIDA, Júlio Alfredo de. A adoção intuitu

personae - uma proposta de agir. Síntese

da Monografia de Especialização em Direito

Comunitário: Infância e Juventude, 2002. Fundação

Escola Superior do Ministério Público. Disponível em: <http://www.mp.rs.gov.br/infancia/doutrina/id393.

htm>. Acesso em: 30 out. 2012.

AMIN, Andréa Rodrigues et al. Curso de direito da criança e do adolescente: aspectos teóricos e práticos. 2.ed. rev., atual. Rio de Janeiro: Lumen Juris, 2007. 894p.
BEZERRA, Carlos. Projeto de Lei no 1212 de

2011. Disponível em: <http://www.camara.gov.br/ proposicoesWeb/prop_mostrarintegra;jsessionid $=30$ E060459747BAEF147EC1DC5E9475D7.node1?codt eor $=865458$ \&filename $=P L+1212 / 2011>$. Acesso em: 26 out. 2012.

BRASIL. Constituição: República Federativa do Brasil de 1988. Brasília, DF: Senado Federal, 1988.

BRASIL. Lei 8.069, de 13 de Julho de 1990. Estatuto da Criança e do Adolescente. Disponível em: <http:// www.planalto.gov.br/ccivil_03/leis/L8069.htm>. Acesso em: 04 maio 2012.

BRASIL, Superior Tribunal de Justiça. Súmula n. 99, de 14 de abril de 1994. O Ministério Público tem legitimidade para recorrer no processo em que oficiou como fiscal da lei, ainda que não haja recurso da parte. Diário da Justiça, Brasília-DF, 25 de abril de 1994. Disponível em: <http://www.dji.com.br/ normas_inferiores/regimento_interno_e_sumula_ stj/stj_0099.htm>. Acesso em: 12 jun. 2012.

BRASIL. Convenção relativa à proteção das crianças e à cooperação em matéria de adoção internacional. Decreto $n^{0} 3.087$ de 21 de Junho de 1999. Disponível em: <http://www.planalto.gov.br/ccivil_03/decreto/ d3087.htm>. Acesso em: 10 out. 2012.

BRASIL. Código Civil. Lei 10.406, de 10 de janeiro de 2002. Disponível em: <http://www.planalto.gov. br/ccivil_03/leis/2002/l10406.htm>. Acesso em: 4 maio 2012.

BRASIL, Tribunal de Justiça do Estado do Rio de Janeiro. Apelação Cível n. 2004.001.11029. Relator Des. José C. Figueiredo. Julgado em 16/06/2004.

BRASIL, Superior Tribunal de Justiça. Súmula n. 383, de 27 de maio de 2009. A competência para processar e julgar as ações conexas de interesse de menor é, em princípio, do foro do domicílio do 
detentor de sua guarda. Diário da Justiça, BrasíliaDF, 08 de junho de 2009. Disponível em: <http:// www.dji.com.br/normas_inferiores/regimento_ interno_e_sumula_stj/stj__0383.htm >. Acesso em: 12 jun. 2012.

DANTAS, Danilo Sérgio Moreira. A nova lei nacional de adoção (Lei 12.010, de 29 de julho de 2009) e as novas diretrizes para a adoção no Brasil, à convivência familiar e garantias dos adotandos. 2 dez. 2009. Disponível em: <http://www.jurisway. org.br/v2/dhall.asp?id_dh=3282>. Acesso em: 23 abr. 2012.

DIAS, Maria Berenice. Adoção e a espera do amor. Disponível em: <http://www.mbdias.com.br/ hartigos.aspx?28,8>. Acesso em: 28 out. 2012.

DIAS, Maria Berenice. Manual de direito das famílias. 5.ed. rev., atual. e ampl. São Paulo: Revista dos Tribunais, 2009. 608p.

DINIZ, Maria Helena. Curso de direito civil brasileiro. 18.ed. v.5. aum. e atual. São Paulo: Saraiva, 2002. 572p.

FARIAS, Cristiano Chaves de, ROSENVALD, Nelson. Direito das famílias. 2.ed. ver., atual. e ampl. Rio de Janeiro: Lumen Juris, 2010. 945p.

GRANATO, Eunice Ferreira Rodrigues. Adoção: doutrina e prática. 2.ed. Curitiba: Juruá, 2010. 202p.

ISHIDA, Válter Kenji. Estatuto da criança e do adolescente: doutrina e jurisprudência. 11.ed. São Paulo: Atlas, 2010. 590p.

JUS BRASIL: Jurisprudência. Jurisprudência unificada, atualizada diariamente.

Disponível em: <http://www.jusbrasil.com.br/ jurisprudencia/19793244/apelacao-civel-ac70041924887-rs-tjrs>. Acesso em: 31 jul. 2012.
JUS BRASIL: Jurisprudência. Jurisprudência unificada, atualizada diariamente. Disponível em: <http://www. jusbrasil.com.br/jurisprudencia/9115155/recursoespecial-resp-1172067-mg-2009-0052962-4-stj>. Acesso em: 22 out. 2012.

JUS BRASIL: Jurisprudência. Jurisprudência unificada, atualizada diariamente.

Disponível em:<http://www.jusbrasil.com.br/ jurisprudencia/17512803/apelacao-civel-ac-43812rn-2010004381-2-tjrn>. Acesso em: 22 out. 2012.

JUS BRASIL: Jurisprudência. Jurisprudência unificada, atualizada diariamente.

Disponível em: < http://www.jusbrasil.com.br/ jurisprudencia/20301181/apelacao-civel-ac-349016sc-2011034901-6-tjsc>. Acesso em: 28 out. 2012.

JUS BRASIL: Jurisprudência. Jurisprudência unificada, atualizada diariamente.

Disponível em: <http://www.jusbrasil.com.br/ jurisprudencia/15931404/apelacao-civel-ac-41447rn-2010004144-7-tjrn>. Acesso em: 28 out. 2012.

KUSANO, Suely Mitie. Adoção intuitu personae. 2006. 75f. Tese (Doutorado em direito) - Pontifícia Universidade Católica, São Paulo, 2006. Disponível em: <http://www.dominiopublico.gov.br/pesquisa/ DetalheObraForm.do?select_action=\&co_ obra=30671>. Acesso em: 28 out. 2012.

LIBERATI, Wilson Donizeti. Adoção internacional. Convenção de Haia: reflexos na legislação brasileira. Rondônia-RO. Disponível em: <http://www.abmp. org.br/textos/317.htm>. Acesso em: 10 out. 2012.

MADALENO, Rolf. Curso de direito de família. 3.ed. atual. e ampl. Rio de Janeiro: Forense, 2009. 906p.

MATOS, João. Projeto de Lei no 1756 de 2003.

Disponível em: <http://www.camara.gov.br/ proposicoesWeb/prop_mostrarintegra?codteor $=15599$ 5\&filename=PL+1756/2003>. Acesso em: 26 out. 2012. 
PEREIRA, Rodrigo da Cunha. Pai, por que me abandonaste? In: PEREIRA, Tânia da Silva. 0 melhor interesse da criança: um debate interdisciplinar. Rio de Janeiro: Renovar, 2000. p.585.

\section{RAMOS, Elisa Maria Rudge. STJ admite a adoção}

“intuito personae" (informativo 385). 13 mar. 2009.
Disponível em: <http://www.lfg.com.br/public_html/ article.php?story=20090313150247907 >. Acesso em: 25 abr. 2012.

ROSSATO, Luciano Alves; LÉPORE, Paulo Eduardo. Comentários à lei nacional de adoção. São Paulo: RT, 2009. 
Data da submissão: 7 de Junho de 2017

Avaliado em: 19 de Julho de 2017 (Avaliador A)

Avaliado em: 27 de Agosto de 2017 (Avaliador B)

Aceito em: 28 de Agosto de 2017
1. Mestre em Direito pela Universidade Federal de Santa Catarina. Advogada e professora do curso de Direito da Unoesc, Campus de São Miguel do Oeste, Pinhalzinho e Maravilha. E-mail: fernandatrentin@hotmail.com

2. Bacharel em Direito pela Unoesc, Campus de São Miguel do Oeste. Advogada. E-mail: pamelafao@hotmail.com 